\title{
Pengaruh Keterampilan Mengajar Guru terhadap Aktivitas Belajar Siswa SD Negeri 04 Loning
}

\author{
Jupriyanto $^{1}$, Nuridin ${ }^{2}$ \\ ${ }^{1)}$ Prodi PGSD, FKIP Universitas Islam Sultan Agung, Semarang, Indonesia \\ E-mail: jupriyanto@unissula.ac.id \\ ${ }^{2)}$ Universitas Islam Sultan Agung, Semarang, Indonesia \\ E-mail : nuridin@unissula.ac.id
}

\begin{abstract}
Abstrak. Keterampilan mengajar guru penting dalam proses pembelajaran karena salah satu cara guru dapat melakukannya sehingga proses pembelajaran di kelas menumbuhkan kegiatan belajar siswa yang efektif. Aktivitas adalah prinsip penting dalam proses pembelajaran. Kegiatan siswa tidak cukup hanya dengan mendengarkan dan membuat catatan, tetapi lebih kompleks dari itu. Semakin tinggi kegiatan belajar siswa, semakin tinggi peluang keberhasilan pengajaran. Ini berarti keterampilan mengajar guru harus mampu membuat siswa merangsang berbagai kegiatan belajar. Tujuan penelitian ini adalah untuk mengetahui pengaruh keterampilan mengajar guru terhadap aktivitas siswa di SD Negeri 04 Loning. Penelitian ini menggunakan metode kuantitatif tepatnya desain penelitian $e x$ - post facto dengan menggunakan korelasi. Sedangkan untuk analisis penyuling data menggunakan bantuan program SPSS 16.00. Hasil penelitian menunjukkan bahwa dari data diperoleh nilai $\mathrm{t}=7,408$ dengan siginifakansi $0,000<0,05$ maka Ho ditolak artinya ada pengaruh yang signifikan terhadap keterampilan mengajar guru terhadap aktivitas belajar siswa.
\end{abstract}

Kata Kunci: Keterampilan Mengajar; Kegiatan Belajar

\section{PENDAHULUAN}

Proses pembelajaran membutuhkan seorang guru yang merupakan tenaga profesional mengandung makna ahli dan bertanggungjawab atas kewajiban yang diembannya. Pendidikan merupakan salah satu sarana strategis bagi peningkatan mutu sumber daya manusia [1]. Pendidikan disebut sebagai pondasi utama dalam pembentukan generasi penerus bangsa. Kemajuan dari suatu bangsa dapat ditengok melalui pendidikannya. Hal ini sama halnya dengan pendidikan sebagai tolak ukur kemajuan suatu bangsa.

Pencapaian tujuan secara optimal, segala komponen dalam pendidikan harus saling bersinergi. Salah satu komponen penting dalam pendidikan adalah guru. Mendidik, mengajar, dan melatih menjadi tugas yang melekat pada profesi mulia pembawa amal tidak terputus yaitu ilmu yang bermanfaat yang erat melekat pada citra pendidik. Mempunyai kompetensi merupakan hal yang esensial yang harus ada pada diri seorang pendidik. Kompetensi itu harus ada pada diri seorang guru yang dapat dilihat dari kemampuannya.

Kompetensi yang harus dimiiliki guru yang menjadi komponen penting dalam pendidikan ialah kompetensi pedagogik, kompetensi kepribadian, kompetensi profesional dan kompetensi sosial [2]. Keempat kompetensi ini haruslah tercermin dalam diri seorang pendidik yang diimplementasikan dalam pembelajaran di sekolah. Dilihat dari cara berinteraksi dengan orang lain, sikap-sikap yang patut diteladani dan mampu menguasai materi serta menyampaikannya dengan cara yang tepat dan disesuaikan dengan potensi sekolah. Kemampuankemampuan tersebut termasuk ke dalam keterampilan guru dalam mengajar.

Keterampilan mengajar ialah kecakapan guru dalam menyajikan materi pelajaran antara lain, menguasai bahan pengajaran mampu memilih metode yang tepat dan penguasaan kelas dengan baik [3]. Keterampilan tersebut tercermin dalam proses 
pembelajaran guru bertanya, membuka menutup pembelajaran, dan cara dalam menyampaikan materi pembelajaran. Menurut [4] seorang guru yang memiliki kemampuan keterampilan mengajar dalam melakukan pengajaran kepada siswanya agar siswa dapat memahami pelajaran yang akan diajarkan. Oleh karena itu guru harus terampil dan selalu mempunyai trik untuk bisa membuat suasana menjadi lebih menyenangkan sehingga aktivitas siswa tidak membosankan.

Guru dituntut untuk terampil dalam melakukan proses pembelajaran karena dengan adanya guru yang terampil maka berdampak positif bagi siswa. Dibuktikan pada keterampilan guru dalam mengajar seperti guru terampil dalam membuka dan menutup pelajaran, mengelola kelas, mengadakan variasi, keterampilan bertanya dan keterampilan dalam memberikan penguatan yang sesuai dengan keadaan siswa maka siswa akan menerima dan menganggap guru tersebut adalah guru yang menyenangkan. Dengan menyenangkannya seorang guru bagi siswa akan membawa dampak tersendiri seperti siswa antusias dan efektif dalam mengikuti pelajaran yang disampaikan oleh guru yang terampil tersebut. Maka, penting sekali keterampilan seorang guru dalam proses pembelajaran.

Tergugahnya rasa antusias siswa dalam pembelajaran akan memicu mereka untuk semangat dan terfokus dalam pembelajaran. Pembelajaran yang memiliki makna hingga membekas di benak siswa akan terasa. Keterampilan mengajar ini menjadi bekal guru dalam menarik siswanya untuk selalu mengikuti pembelajaran dengan perasaan bahagia yang nantinya membuat mereka mudah untuk mengkontruksikan pengetahuan mereka.

Proses pembelajaran meliputi aktivitas guru dengan aktivitas siswa. Pelaksanaan proses pembelajaran menuntut guru untuk memfokuskan pada setiap siswanya, yaitu pada aspek biologis, intelektual dan psikologisnya. Oleh karena itu, tampaklah dua posisi subjek di mana guru bertindak sebagai pihak yang mengajar sekaligus pemegang kunci keberhasilan proses pembelajaran, sedangkan siswa adalah pihak yang belajar untuk mendewasakan diri. Hubungan guru dengan siswa harus berdasarkan hal-hal yang mendidik untuk pencapaian tujuan [5].

Pada dasarnya aktivitas siswa itu tidak hanya mencatat atau mendengarkan guru saja melainkan lebih kompleks dari itu. Oleh sebabitu guru harus meningkatkan kegiatan mengajarnya sehingga siswa dapat merangsang melakukan berbagai aktivitas belajar [6].

Pembelajaran haruslah bersifat holistic dimana seluruh siswa terlibat aktif di dalam pembelajaran. Segala aspek dalam diri siswa dapat dikembangkan dan disalurkan dalam proses pembelajaran. Pengontruksian ilmu pengetahuan akan lebih mudah dilakukan dengan hal demikian. Untuk itu, siswa perlu dirangsang untuk melakukan aktivitas-aktivitas dalam belajar di kelas. Siswa tidak hanya diposisikan sebagai pendengar dan pencatat guru harus meningkatkan kegiatan mengajarnya sehingga siswa dapat merangsang melakukan berbagai aktivitas belajar.

Dapat peneliti kemukakan bahwa masih terdapat kesenjangan pada saat proses pembelajaran yang terjadi, dapat dilihat saat pembelajaran berlangsung siswa diajukan pertanyaan oleh guru dan belum berani dijawab oleh siswa dan sebaliknya apabila diberikan kesempatan untuk bertanya masih tetap tidak ada siswa yang memanfaatkannya, bahkan ketika ada bagian yang belum mereka pahami mereka tidak berani menyampaikan apa yang belum mereka pahami dari materi yang telah disampaikan oleh guru.

Proses pembelajaran guru juga terkesan masih kurang menarik. Hal ini dapat dilihat pada saat proses pembelajaran dimana guru masih kurang terampil dalam mengajar. Dalam membuka dan menutup pelajaran, pengelolaan kelas masih kurang terampil dilihat dari siswa yang kebanyakan dari mereka tidak terfokus dan tidak memperhatikan guru. Dalam hal bertanya dan memberikan apersepsi kepada siswanya guru masih terlihat kaku dan stimulus sulit diterima oleh siswa. Penguatan dalam proses pembelajaran juga kurang diberikan. Variasi dalam mengajar kurang diterapkan terlihat dari cara penyampaian materi pembelajaran dimana penyampaian pembelajaran guru juga terkesan monoton. Guru hanya lebih sering memberi tugas dan ceramah sehingga dalam penyampain materi pembelajaran tidak sesuai antara isi materi yang disampaikan.Siswa terlihat kurang tergugah dalam pembelajaran yang mempengaruhi motivasi mereka di dalam pembelajaran. Hal inilah yang banyak menyebabkan siswa tidak fokus atau tidak memperhatikan apa yang sedang diajarkan pada saat proses pembelajaran.

Adanya penelitian ini diharapkan dapat memberikan manfaat berupa informasi mengenai pengaruh keterampilan mengajar guru terhadap aktivitas belajar siswa. Dengan mengetahui manfaat dari keterampilan mengajar guru nantinya dapat menginspirasi guru untuk lebih meningkatkan keterampilannya dalam mengajar guna menciptakan suasana belajar yang menyenangkan dan tidak membosankan. Sikap berani bertanya dan bertanya siswa juga dapat ditingkatkan melalui aktivitasaktivitas belajar yang diberikan pada siswanya. 


\section{METODE PENELITIAN}

Dalam penelitian ini digunakan penelian $e x$ post facto dengan menggunakan korelasi tujuannya yaitu untuk diketahui pengaruh variabel bebas yaitu (X) dengan variabel terikat yaitu (Y). Penelitian ini menggunakan pendekatan kuantitatif. Selain itu peneliti menggunakan model penelitian paradigma sederhana, yaitu terdapat satu variabel bebas/independent yaitu ketrampilan mengajar guru dan satu variabel terikat/dependent yaitu aktivitas belajar siswa.

Populasi dalam penelitian ini yaitu seluruh siswa SD Negeri 04 Loning sebanyak 342 siswa. Dalam pengambilan sampel, peneliti menggunakan teknik sampling berimbang (Proportional random sampling) yaitu 163 siswa. Dalam penelitian ini instrumen yang digunakan yaitu lembar angket keterampilan mengajar guru dan aktivitas belajar siswa, serta dokumentasi.

Uji coba instrumen dilakukan dengan menggunakan validitas isi. Menurut [7] instrumen yang valid berarti alat ukur yang digunakan untuk mendapatkan data (mengukur) itu valid. Setelah dilakukan uji ahli, maka diperoleh skor validitas isi angket yang akan dipakai dalam penelitian.

Analisis data merupakan proses penyederhanaan data ke dalam bentuk yang lebih mudah dibaca dan diintreprestasikan. Untuk kegiatan analisis data kuantitatif maka diterapkan dengan analisis statistik adapun rumus statistik yang akan digunakan untuk menganalisis data dengan uji normalitias, uji linieritas dan uji hipotesis.

\section{HASIL DAN PEMBAHASAN}

Penelitian mulai dilakukan dari mengumpulkan informasi yang dibutuhkan sebelum melakukan penelitian dengan observasi disekolah untuk mengetahui permasalahan disekolah tersebut berkaitan dengan keterampilan mengajar guru dan aktivitas belajar siswa.

Populasinya yaitu siswa SD Negeri 04 Loning sebanyak 342 siswa. Dalam pengampilan sampel, peneliti menggunakan cara sampling yang digunakan adalah metode sampling berimbang (Proportional random sampling) yaitu 163 siswa. Instrumen ini menggunakan pemungutan data penelitian menggunakan lembar angket keterampilan mengajar guru dan aktivitas belajar siswa, serta dokumentasi.

Berdasarkan data variabel keterampilan mengajar guru adapun skor tetinggi sebesar 27 dan skor terendah 20. Nilai mean sebesar 22,5, nilai median sebesar 22, nilai modus 22 dan standar deviasi 1,51. Hasil analisis deskriptif pada data variabel keterampilan mengajar guru dapat dilihat pada tabel berikut ini.

Tabel 1

Distribusi Frekuensi Variabel Keterampilan Mengajar

\begin{tabular}{llll}
\hline Interval & Frekuensi & Presentase & Kriteria \\
\hline $31-37$ & 0 & $0 \%$ & \\
$24-30$ & 116 & $71,1 \%$ & Sangat tinggi \\
$17-23$ & 47 & $28,9 \%$ & Tinggi \\
$10-16$ & $0 \quad 0 \%$ & & Sendah \\
\hline
\end{tabular}

Dari tabel 1 di atas dapat dideskripsikan bahwa hasil penelitian keterampilan mengajar yang termasuk kategori rendah sebanyak 47 siswa dengan presentase $28,9 \%$ sedangkan yang termasuk kategori tinggi sebanyak 116 siswa dengan presentase $71,1 \%$. Jadi dapat disimpulkan bahwa keterampilan mengajar guru di SD Negeri 04 Loning termasuk dalam kategori tinggi.

Berdasarkan data variabel aktivitas belajar siswa adapun skor tetinggi sebesar 26 dan skor terendah 18 . Nilai mean sebesar 21,1 , nilai median sebesar 21, nilai modus 21 dan standar deviasi 1,54. Hasil analisis deskriptif pada data variabel aktivitas belajar dapat dilihat pada tabel berikut ini.

Tabel 2

Distribusi Frekuensi Variabel Aktivitas Belajar

\begin{tabular}{llll}
\hline Interval & Frekuensi & Presentase & Kriteria \\
\hline $31-37$ & 0 & $0 \%$ & Sangat tinggi \\
$24-30$ & 150 & $92,1 \%$ & Tinggi \\
$17-23$ & 13 & $7,90 \%$ & Rendah \\
$10-16$ & 0 & $0 \%$ & Sangat rendah \\
\hline
\end{tabular}

Dari tabel 2 di atas dapat dideskripsikan bahwa hasil penelitian aktivitas belajar yang termasuk kategori rendah sebanyak 13 siswa dengan presentase $7,9 \%$ sedangkan yang termasuk kategori tinggi sebanyak 150 siswa dengan presentase $92,1 \%$. Jadi dapat disimpulkan aktivitas belajar siswa di SD Negeri 04 Loning termasuk kategori tinggi.

Uji mormalitas di gunakan dalam penelitian ini yaitu uji kolmogrov-smirnov dengan dibantu program SPSS 16 for windows. Output yang dihasilkan adalah sebagai berikut: 


\begin{tabular}{|c|c|c|}
\hline \multicolumn{3}{|c|}{$\begin{array}{c}\text { Tabel } 3 \\
\text { Output Uji Kolmogrov-Smirnov }\end{array}$} \\
\hline & $\begin{array}{l}\text { Ket. } \\
\text { Mengajar }\end{array}$ & $\begin{array}{l}\text { Aktivitas } \\
\text { Belajar }\end{array}$ \\
\hline & 163 & \\
\hline \multirow{2}{*}{ Normal Paramaters } & 22.5215 & 21.4908 \\
\hline & 1.51673 & 1.62301 \\
\hline \multirow{2}{*}{ M. Extreme Diff. } & & \\
\hline & .205 & .122 \\
\hline Negative & -.124 & \\
\hline \multirow{2}{*}{$\begin{array}{l}\text { Kolmogorov-Smirnov Z } \\
\text { Asymp Sig. (2-tailed) }\end{array}$} & 2.618 & \\
\hline & .000 & \\
\hline \multicolumn{3}{|c|}{$\begin{array}{l}\text { Dari tabel } 3 \text { di atas, dapat dilihat bahwa } \\
\text { keduanya memiliki sig. yang lebih dari taraf } \\
\text { signifikasi } 0,05 \text {. Hal itu bisa terlihat dari perolehan } \\
\text { normalitas data perolehan pengujian nilai angket } \\
\text { keterampilan mengajar sebesar } 2,618 \text { dan aktivitas } \\
\text { belajar sebesar 1,556. kesimpulannya kedua data } \\
\text { termasuk layak karena sig. > 0,05. Setelah } \\
\text { melakukan analisa data awal, kemudian dilanjutkan } \\
\text { dengan analisis data akhir yaitu uji hipotesis tepatnya } \\
\text { dengan uji regresi linier sederhana. Output dari uji } \\
\text { regresi linier sederhana ditampilkan dalam tabel di } \\
\text { bawah ini. }\end{array}$} \\
\hline
\end{tabular}

Tabel 4

Output Uji Linier Sederhana

\begin{tabular}{lrcccc}
\hline & \multicolumn{2}{c}{$\begin{array}{l}\text { Unstandardized } \\
\text { Coefficients }\end{array}$} & \multicolumn{3}{c}{$\begin{array}{c}\text { Standardized } \\
\text { Coefficients }\end{array}$} \\
\hline Model & \multicolumn{1}{c}{ B } & Std.Error & Beta & t & Sig \\
\hline Constant & 14.826 & 1.829 & 8.10 & & .000 \\
Ket.Meng & .296 & .081 & .277 & 3.65 & .000 \\
\hline
\end{tabular}

Berdasarkan hasil data angket keterampilan mengajar guru dan aktivitas belajar siswa menunjuk bahwa ada dampak yang penting antara keterampilan mengajar guru terhadap aktivitas belajar siswa. Nilai $t_{\text { }}{ }_{\text {y }}$ pada hasil uji regresi linear sederhana yaitu 7,408 dan nilai sig. $=0,00$ sebab nilai sig. $<0,05$ jadi Ho didapat. Berarti terdapat pengaruh keterampilan mengajar guru terhadap aktivitas belajar siswa SD Negeri 04 Loning.

Guru sebagai seorang yang berperan sangat penting di dalam proses pembelajaran maka dari itu jika tidak ada guru lalu cara belajar yang dilangsungkan takan maksimal. Oleh sebab itu diperlukannyaguru yang terampil agar menunjang penampilanya dalam memberikan materi pelajaran di kelas. Seperti yang dikatakan [8] bahwa "untuk mencapai tingkat efektivitas mengajar yang tinggi harus dapat menguasai perbuatan mengajar yang kompleks, dan perbuatan yang kompleks tidak dapat dikuasai secara langsung".

Guru yang mampu mengatur siswanya serta dapat mengendalikannya dalam kondisi yang lebih baik atau optimal maka akan tercapai pembelajaran yang diinginkan. Seperti yang dikemukakan oleh [9] bahwa guru memiliki kedudukan penting dalam hal tugas dan tanggung jawabnya yang berat dalam mencerdaskan siswanya. Oleh karenanya, pendidik bisa lengkapi dengan semua keterampilan mengajar yang bisa membantu dalam jalannya tugas sehingga berlaku hubungan edukatif bisa di optimalkan di hadapan siswanya.

Pendidik yang memiliki berbagai keterampilan mengajar dan memiliki juga kualifikasi baik sebagai pendidik mata pelajaran akan dapat melaksanakan proses pembelajaran dengan baik. Keterampilan pendidik dalam mengajar tersebut diantaranya dapat dilihat ketika pembukaan, penyajian, dan penutupan pembelajaran, dapat mempergunakan media dan mampu memberikan penguatan serta mampu mengadakan variasi dalam kegiatan pembelajaran, maka dengan demikian terdapat hubungan positif antara penilaian peserta didik terhadap keterampilan guru dalam mengajar.

Keterampilan - keterampilan yang dimiliki guru ditunjang dengan ijazah sarjana bidang administrasi perkantoran yang dimilikinya dan masa kerja yang lama. Disamping itu, pihak sekolah juga berusaha membantu guru untuk meningkatkan keterampilannya dalam mengajar, antara lain dengan mengikut sertakan guru dalam pelatihan - pelatihan yang diselenggarakan oleh pihak terkait yang dapat menambah wawasan dan pengetahuan khususnya mengenai keterampilan mengajar, kepala sekolah melakukan supervisi pada saat guru mengajar sehingga dapat memberikan saran yang berkaitan dengan cara mengajar guru dikelas. Guru juga dibekali dengan pembelajaran dengan teknologi multimedia. Pembaharuan pembelajaran dapat dilakukan dengan media pembelajaran yang efektif dan menarik [10]. Untuk itu, guru harus mau untuk selalu belajar.

Menurut [11] mengatakan bahwa "Guru merupakan asset sekolah yang memiliki karakteristik tersendiri. Setiap guru memiliki latar belakang yang berbeda serta harapan dan tujuan yang berbeda pula". Segala potensi yang ada dalam diri siswa harus mampu dikembangkan oleh guru. Longlife education menjadi modal utama guru untuk selalu menjalankan kiprahnya sebagai seorang guru. Pendidikan seumur hidup menolak pandangan bahwa pendidikan adalah yang lazim kita sebut sebagai sekolah [12]. Dalam mengembangkan potensi yang ada pada diri seorang guru hendaknya selalu dan mau untuk terus belajar dari pengalaman dan perkembangan zaman yang terjadi. Dengan begitu pembelajaran yang menyenangkan akan terwujud. [13] mengungkapkan bahwa guru sebagai suatu subsistem pendidikan nasional merupakan faktor kunci dan memiliki peran 
yang sangat strategis. Dapat disimpulkan bahwa ketercapaian tujuan pendidikan dipengaruhi oleh kinerja guru dalam proses pembelajaran

Proses pembelajaran membutuhkan seorang guru yang merupakan tenaga profesional dengan mempunyai kompetensi. Kompetensi itu harus ada pada diri seorang guru yang dapat dilihat dari kemampuannya. Pembelajaran akan berjalan efektif dan menyenangkan ketika seorang guru mampu dan mahir dalam mengajar.

Berdasarkan deskripsi data penelitian di SD Negeri 04 Loning bahwa keterampilan mengajar guru termasuk dalam kriteria tinggi. Hal ini dapat ditunjukkan dengan terampilnya guru dalam membuka dan menutup pelajaran, mengelola kelas, mengadakan variasi, kurang terampil dalam bertanya dan dalam memberi penguatan yang semuanya dinilai oleh responden dalam kriteria tinggi.

Penelitian ini, ditunjang oleh penelitian lalu yang telah dilakukan oleh Rahmanitia Nadiatus yang berjudul "Pengaruh ketrampilan mengajar guru terhadap motivasi belajar siswa kelas $\mathrm{V}$ pada mata pelajaran sejarah kebudayaan islam di MIT ArRoihan Lawang". Hasil penelitian tersebut menunjukkan bahwa keterampilan belajar berpengaruh secara signifikan terhadap motivasi belajar siswa. dengan itu, teramat penting bagi guru untuk mampu erus belajar guna keterampilan belajar yang dimilikinya. Salah satu faktor penentu keberhasilan belajar adalah keterampilan guru dalam mengajar.

\section{KESIMPULAN}

Dari perolehan penelitian menyinggung pengaruh keterampilan mengajar guru pada aktivitas belajar siswa di SDN 04 Loning menghasilkan kesimpulan, keterampilan mengajar guru berpengaruh pada aktivitas siswa, terbukti nilai nilai $t$ hitung $=7,408$ sama nilai siginifakansi $0,000<0,05$ maka Ho ditolak artinya terdapat dampak yang signifikan pada keterampilan mengajar guru dengan aktivitas belajar siswa SDN 04 Loning.

Walaupun keterampilan mengajar guru memberikan pengaruh yang lebih kecil, tetapi untuk meningkatkan aktivitas belajar siswa hendaknya variabel ini tetap diperhatikan. Karena keberhasilan dari suatu proses pembelajaran tentunya dipengaruhim oleh salah satu faktor yakni keterampilan guru dalam mengajar.

Ucapan terima kasih disampaikan kepada seluruh pihak yang terlibat dalam penelitian ini. Kepada Fakultas Keguruan dan Ilmu Pendidikan khususnya Program Studi Pendidikan Guru Sekolah
Dasar Universitas Islam Sultan Agung yang telah memfasilitasi penelitian ini.

\section{DAFTAR PUSTAKA}

[1] Sutardi, S. (2016). Pengaruh Kompetensi Guru, Motivasi Belajar, dan Lingkungan Keluarga terhadap Hasil Belajar Mata Pelajaran Ekonomi. Jurnal Pendidikan IPS , 3 (2), 188-189

[2] Daryanto, \& Farid, M. (2015). Konsep Dasar Manajemen Pendidikan di Sekolah. Yogyakarta: Gava Media

[3] Sundari, d. (2014). Optimalisasi Peningkatan Keterampilan Mengajar Mahasiswa dengan Menarapkan Model Berbasis Masalah dalam Pembelajaran IPS di SD. Edu Humaniora , 2 (2), 125-135

[4] Kusnadi. (2008). Strategi Pembelajaran Ilmu Pengetahuan. Pekanbaru: Yayasan Pusaka Riau

[5] Riduwan. (2010). Belajar Mudah Penelitian untuk Pemula. Bandung: Alfabeta

[6] Sudjana, N. (2009). Dasar Dasar Proses Belajar Mengajar. Bandung: Sinar Baru Algensin

[7] Sugiyono. (2015). Metodologi Penelitian Kuantitatif Kualitatif $R \& D$. Bandung: Alfabeta.

[8] Hasibuan, J., \& Moedijono. (2012). Proses Belajar Mengajar. Bandung: Rosdakarya

[9] Djamarah, S. (2010). Guru dan Siswa dalam Interaksi Edukatif. Jakarta: Rineka Cipta

[10] Jupriyanto, \& Turahmat. (2017). Bahan Ajar Multimedia Interaktif Ilmu Pengetahuan Alam Sebagai Media Pembelajaran Inovatif. Jurnal Ilmiah Pendidikan Dasar, 4 (2), 119-128

[11] Nuridin. (2012). Pengaruh Kemampuan Manajerial dan Kematangan Bawahan terhadap Efektifitas Gaya Kepemimpinan Kepala Sekolah. Majalah Ilmiah Sultan Agung , 1 (127), 1-20

[12] Ahmadi, R. (2014). Pengantar Pendidikan. Yogyakarta: Ar-Ruzz Media

[13] Kasmawati. (2015). Pengaruh Guru Profesional terhadap Motivasi Belajar Peserta Didik pada SMPN 1 Botoramba Kabupaten Jeneponto. Jurnal Pendidikan Islam , 2(1), 4264 